Journal Homepage: http://journal.umg.ac.id/index.php/tiaa

JIATAX 3 (1) 36-44 (2020)

\title{
Analisis Pemanfaatan Teknologi Informasi, Sosialisasi Pajak, Pengetahuan Pajak, Ketepatan Penyampaian SPT Terhadap Kenaikan Pendapatan Pajak
}

\author{
Lidia Andiani ${ }^{11}$ \\ ${ }^{1,}$ STIE Malangkucecwawa, Jl. Terusan Candi Kalasan, Malang, Indonesia
}

http://dx.doi.org/10.30587/jiatax.v3i1.1526

\begin{abstract}
The purpose of this study was to determine the effect of simultaneous and partial variables on the use of information technology, tax socialization, taxation knowledge, and the accuracy of the delivery of tax returns to the increase in tax revenue. The type of research method used is the explanatory research method with a quantitative approach using statistical analysis instruments. This study examines five variables, namely four independent variables and one dependent variable. The results showed that partially the use of information technology variables, tax socialization variables, the variable of the accuracy of the delivery of tax returns had a significant effect on the variable increase in tax revenue. While the tax knowledge variable has no significant effect on the increase in tax revenue. Utilization of information technology, tax socialization, tax knowledge, and accuracy of the delivery of SPT together influence the revenue increase of the Blitar Tax Office
\end{abstract}

Type of Paper: Empirical

Keywords: Firm Performance, Capital Structure, Trade-off Theory, Agency Theory, Growth

\section{Pengantar}

Sumber penerimaan negara terdiri dari beberapa unsur yaitu keuntungan perusahaan negara, pinjaman, perpajakan, bantuan, denda atau sita, pencetakan uang. Dari unsur sumber penerimaan negara tersebut perpajakan merupakan sumber penerimaan negara yang paling besar dan selalu bisa ditingkatkan jumlahnya baik dengan usaha ekstensifikasi maupun intensifikasi pajak. Pajak juga mempunyai resiko yang paling rendah dalam proses pemungutannya.

Seiring dengan perkembangan perekonomian maka peran pajak menjadi sangat penting dan kendala yang paling besar adalah penghindaran pajak. Dan penghindaran ini akan berpengaruh terhadap jumlah penerimaan pajak. Untuk itulah maka penelitian ini dilakukan untuk mengetahui seberapa besar pengaruh variabel ini terhadap kenaikan pendapatan dari pajak.

\footnotetext{
${ }^{1}$ Kontak penulis:

Email: lidia@stie-mce.ac.id

Afiliasi: STIE Malangkucecwara
} 


\section{Lidia Andiani}

Perkembangan teknologi informasi saat ini sangat pesat dan semua bidang diwajibkan untuk mengikuti perkembangan tersebut. Semua kegiatan saat ini tidak lepas dari penggunaan teknologi karena disamping untuk mempermudah juga untuk mempercepat penyelesaian. Demikian juga dengan pajak juga tidak lepas dengan penggunaan teknologi informasi berkaitan dengan pelaporan pajak. Adapun e-system perpajakan dibagi menjadi e-registration, e-filing dan e-Billing;

Sosialisasi yang diberikan kepada masyarakat dimaksudkan untuk memberikan pengertian kepada masyarakat akan pentingnya membayar pajak.. Salah satu faktor yang bisa ditekankan oleh aparat dalam meningkatkan kesadaran dan kepatuhan pajak adalah dengan cara mensosialisasikan peraturan pajak baik itu melalui penyuluhan, seruan moral baik dengan media billboard, baliho, maupun membuka situs peraturan pajak yang setiap saat bisa diakses oleh Wajib Pajak. Di samping itu KPP juga menyelenggarakan sosialisasi dalam bentuk pelatihan kebijakan baru yang dilakukan misalnya terkait tax amnesty, penghitungan $\mathrm{PPh}$, dan lain-lain

Pemisahan antara fungsi kepemilikan dengan fungsi pengelolaan menjadi semakin nyata. Berbagai keterbatasan, pemilik sumber daya (Capital suppliers/principals) mempercayakan (trust = amanah) pengelolaan sumber daya tersebut kepada pihak lain (steward = manajemen) yang lebih capable dan siap. Kontrak hubungan antara stewards dan principals atas dasar sehingga model yang sesuai pada kasus organisasi sektor publik adalah stewardship theory Kepatuhan pajak identik dengan kesediaan seorang wajib pajak dalam memenuhi peraturan perpajakannya.

Ketepatan SPT dalam Prinsip self-assessment, dalam pemenuhan kewajiban perpajakan adalah bahwa Wajib Pajak (WP) diwajibkan untuk menghitung, memperhitungkan, membayar sendiri, dan melaporkan pajak yang terutang sesuai ketentuan peraturan perundang-undangan perpajakan.

Kenaikan Pendapatan : Kepatuhan Wajib Pajak merupakan aspek yang penting dalam meningkatkan penerimaan negara dari sektor pajak. Apabila wajib Pajak yang patuh dalam membayar dan melaporkan SPT terus meningkat maka akan semakin meningkatkan rasio kepatuhan pajak sehingga berpengaruh kepada pendapatan negara dari sektor pajak.

\section{Tinjauan Pustaka}

\subsection{Pengertian dan Fungsi Pajak}

Pajak menurut Pasal 1 Ayat 1 Undang-Undang Nomor 6 Tahun 1983 sebagaimana telah disempurnakan terakhir dengan Undang-Undang Nomor 28 Tahun 2007 tentang Ketentuan Umum dan Tata Cara Perpajakan adalah kontribusi wajib kepada negara yang terutang oleh orang pribadi atau badan yang bersifat memaksa berdasarkan Undang-Undang dengan tidak mendapat timbal balik secara langsung dan dipergunakan untuk keperluan negara bagi sebesarbesarnya kemakmuran rakyat. Ciri-ciri dari pajak adalah 1 . Pajak dipungut berdasarkan UU serta aturan sifat pelaksanaannya yang dapat dipaksakan;2. Dalam pembayaran pajak tidak dapat ditunjukkan adanya kontraprestasi secara langsung dari pemerintah; c. Pajak diperuntukkan bagi pengeluaran umum pemerintah serta keperluan negara untuk sebesarbesarnya kemakmuran rakyat. Fungsi pajak adalah : 1. Fungsi Finansial atau Fungsi Budgetair yaitu fungsi pajak sebagai salah satu sumber penerimaan negara; 2. Fungsi Mengatur /Fungsi Regulerend yaitu fungsi pajak sebagai salah alat kebijakan sosial ekonomi masyarakat.

\subsection{Persepsi Masyarakat}

Persepsi masyarakat mengenai keadilan sistem perpajakan yang berlaku di suatu wilayah sangat mempengaruhi pelaksanaan perpajakan yang baik di negara tersebut. Persepsi masyarakat ini akan mempengaruhi perilaku kepatuhan pajak dan perilaku penghindaran pajak. 


\section{Lidia Andiani}

Masyarakat mempunyai kecenderungan tidak patuh dan menghindari kewajiban pajak jika merasa sistem pajak yang berlaku tidak adil. Richardson (2006) mengungkapkan 5 dimensi dasar yang dalam melihat proses keadilan pajak dalam suatu negara yang berpengaruh pada perilaku kepatuhan pajak yang ditujukan pada wajib pajak orang pribadi yaitu : 1. Keadilan Umum (General Fairness). Keadilan umum dalam sistem pajak merupakan suatu keadaan dimana keseluruhan lapisan masyarakat secara sadar menyadari bahwa sistem pajak yang dilakukan pemerintah selama ini sudah efektif dan efisien sehingga masyarakat dapat secara langsung merasakan dampak positif dari pembayaran pajak yang mereka bayar kepada negara. Keadilan umum terdapat distribusi beban pajak haruslah berpijak pada kondisi ekonomi suatu negara dan juga pada tingkat penghasilan rata-rata yang diperoleh masyarakat; 2 . Timbal Balik Pemerintah yaitu berhubungan dengan manfaat yang diterima dari pemerintah sebagai imbalan atas pajak penghasilan yang dibayar. Timbal balik pemerintah ini juga bisa diberikan dalam bentuk sosialisasi pajak kepada masyarakat sehingga masyarakat paham apa saja kewajiban dan hak serta kebijakan baru yang dikeluarkan oleh pemerintah.3. Ketentuan-Ketentuan Khusus berhubungan dengan pembayar pajak yang tidak membayar pajak penghasilan mereka secara adil dan adanya ketentuan-ketentuan khusus, tarif khusus yang pemerintah berikan terhadap wajib pajak tertentu dan pengurangan yang hanya diberikan kepada kelompok khusus yang memiliki penghasilan tertentu. Hal ini tercermin misalnya pada pemberlakuan tax amnesty; 4. Struktur Tarif Pajak Yang Lebih Disukai yang berhubungan dengan struktur tarif pajak yang lebih disukai seperti misalnya ketentuan PTKP yang harus selalu ditinjau ulang, pengenaan tarif $\mathrm{PPh}$, kemudahan dalam penyampaian pelaporan, dll. 5. Kepentingan Pribadi berkaitan dengan jumlah pajak yang dibayar secara pribadi terlalu tinggi dan dibandingkan dengan orang lain. Kepentingan pribadi merupakan suatu dorongan bagi seorang wajib pajak untuk membayar pajak kepada pemerintah dengan membandingkan jumlah pajak yang dibayar dengan yang lain, perbandingan ini dilihat melalui tingkat penghasilan yang masing-masing diperoleh. Kepentingan pribadi menjadi salah satu dimensi dari keadilan pajak karena faktor ini dapat membuat masyarakat sadar penuh untuk melakukan tugasnya atau malah enggan dalam membayar pajak. Ketepatan melaporkan SPT termasuk dalam dimensi ini karena mengisi dan melaporkan SPT adalah dasar yang dipakai untuk melakukan pembayaran pajak. Dari landasan teori tersebut dapat disimpulkan hipotesis penelitian ini adalah:

H1: Pemanfaatan teknologi informasi berpengaruh positif terhadap kenaikan pendapatan pajak. $\mathrm{H} 2$ : Sosialisasi pajak berpengaruh positif terhadap kenaikan pendapatan pajak.

H3: Pengetahuan pajak berpengaruh positif terhadap kenaikan pendapatan pajak.

H4: Ketepatan penyampaian SPT positif terhadap kenaikan pendapatan pajak.

\section{Metode Penelitian}

\subsection{Jenis Penelitian}

Jenis metode penelitian yang digunakan adalah metode explanatory research, yaitu penelitian yang menjelaskan hubungan kausal antara variabel-variabel penelitian melalui pengujian hipotesis

\subsection{Variabel Pengukuran}

a. Variabel Independent : Pemanfaatan Teknologi Informasi (X1), Sosialisasi Pajak (X2), Pengetahuan Pajak (X3), Ketepatan Penyampaian SPT (X4)

b. Variabel Dependent : Kenaikan Pendapatan Pajak (Y) 


\section{Lidia Andiani}

\subsection{Skala Pengukuran}

data penelitian ini termasuk data kuantitatif. Data kuantitatif ini diperoleh melalui penyebaran kuesioner yang kemudian diubah menjadi data kuantitatif, disangkakan berupa scoring untuk masing-masing pernyataan dan skala yang digunakan dalam penelitian ini untuk pembobotan item kuesioner adalah menggunakan skala Likert

\subsection{Populasi}

Populasi dalam penelitian ini adalah wajib pajak orang pribadi yang memiliki NPWP lebih dari satu tahun yang berada di wilayah KPP Pratama Blitar. Jumlah populasi sebesar 86.223 wajib pajak

\subsection{Sampel}

Untuk menentukan besarnya sampel dari populasi yang ada, peneliti menggunakan rumus Slovin dalam Hasan (2002: 61) yaitu sebagai berikut :

$$
n=\frac{N}{1+N e^{2}}
$$

Dimana :

$\mathrm{n}$ : ukuran sampel

$\mathrm{N}$ : ukuran populasi

e: persentase kelonggaran ketidaktelitian karena kesalahan pengambilan sampel yang masih dapat ditoleransi, misalnya sebesar satu persen (1\%).

Berikut perhitungan sampel yang digunakan:

$$
\begin{aligned}
& n=\frac{86233}{1+86233 \times 0,01^{2}} \\
& n=99,88
\end{aligned}
$$

Berdasarkan perhitungan besaran sampel yang akan digunakan, diperoleh jumlah sampel sebesar 99,88 sehingga dengan pembulatan ke atas, maka akan digunakan jumlah sampel minimal sebesar 100 orang

\subsection{Teknik Analisis}

Uji Validitas dan Reliabilitas, Uji Regresi Linier Berganda , Uji Asumsi Klasik dan $\mathrm{R}^{2}$ 


\section{Lidia Andiani}

\section{Hasil Penelitian dan Pembahasan}

\subsection{Hasil Uji Validitas}

Uji validitas merupakan suatu ukuran yang digunakan untuk menguji kebenaran instrumen suatu penelitian. Suatu instrumen dinyatakan valid apabila mampu mengungkapkan data dari variabel yang diteliti secara tepat. bahwa nilai $R_{\text {hitung }}$ lebih besar dari nilai $R_{\text {tabel }}$ dan nilai probabilitas (sig) lebih kecil dari $0.05(\alpha=0.05)$. Sehingga dapat dikatakan bahwa semua indikator variabel telah valid.

\subsection{Hasil Uji Reliabilitas}

nilai dari Alpha Cronbach untuk semua variabel lebih besar dari 0,60 sehingga instrumen pernyataan yang digunakan sudah handal (reliable).

\subsection{Analisis Regresi Linier Berganda}

\section{Tabel 1 Hasil Uji Linear Berganda}

\begin{tabular}{|c|c|c|c|c|c|c|}
\hline \multirow{2}{*}{\multicolumn{2}{|c|}{ Model }} & \multicolumn{2}{|c|}{$\begin{array}{l}\text { Unstandardized } \\
\text { Coefficients }\end{array}$} & \multirow{2}{*}{$\begin{array}{l}\text { Standardized } \\
\text { Coefficients } \\
\text { Beta }\end{array}$} & \multirow[t]{2}{*}{$\mathrm{t}$} & \multirow[t]{2}{*}{ Sig. } \\
\hline & & $\mathrm{B}$ & Std. Error & & & \\
\hline \multirow[t]{5}{*}{1} & (Constant) & 0,445 & 0,173 & & $-2,576$ & 0,012 \\
\hline & $\begin{array}{l}\text { Pemanfaatan teknologi } \\
\text { informasi (X1) }\end{array}$ & 0,069 & 0,026 & 0,064 & 2,652 & 0,009 \\
\hline & Sosialisasi Pajak (X2) & 0,162 & 0,042 & 0,162 & 3,834 & 0,000 \\
\hline & Pengetahuan Pajak (X3) & 0,084 & 0,050 & 0,076 & 1,684 & 0,095 \\
\hline & $\begin{array}{ll}\text { Ketepatan } & \text { Penyampaian } \\
\text { SPT (X4) } & \end{array}$ & 0,723 & 0,063 & 0,709 & 11,463 & 0,000 \\
\hline
\end{tabular}

a. Dependent Variable: Kenaikan Pendapatan (Y)

Kesimpulan dari hasil analisis regresi linier berganda diatas yaitu apabila variabel Pemanfaatan teknologi informasi $\left(\mathrm{X}_{1}\right)$, Sosialisasi Pajak $\left(\mathrm{X}_{2}\right)$, Pengetahuan Pajak $\left(\mathrm{X}_{3}\right)$, Ketepatan Penyampaian SPT $\left(\mathrm{X}_{4}\right)$ meningkat maka akan diikuti peningkatan variabel Kenaikan Pendapatan (Y).

\section{Pembahasan}

\subsection{Uji Parsial (Uji t)}

Uji parsial (uji t) digunakan untuk mengetahui apakah masing-masing variabel bebas secara parsial mempunyai pengaruh yang signifikan terhadap variabel terikatnya. Cara pengambilan keputusan dengan membandingkan nilai signifikansi t dengan nilai alpha $(\alpha)$. Apabila nilai signifikansi t <alpha $(\alpha)$ maka $\mathrm{H}_{0}$ ditolak dan $\mathrm{H}_{\mathrm{a}}$ diterima artinya hasilnya signifikan. Sedangkan apabila signifikansi $\mathrm{t}>$ alpha $(\alpha)$ maka $\mathrm{H}_{0}$ diterima dan $\mathrm{Ha}$ ditolak artinya hasilnya tidak signifikan. Hasil uji t dapat dilihat pada tabel 1. 


\section{Lidia Andiani}

Hasil uji t variabel Pemanfaatan teknologi informasi $\left(\mathrm{X}_{1}\right)$ terhadap variabel Kenaikan Pendapatan (Y) menghasilkan nilai signifikansi t sebesar 0,009 . Hasil pengujian tersebut menunjukkan bahwa Sig. $\mathrm{t}<$ alpha $(0,05)$ maka pengaruh variabel Pemanfaatan teknologi informasi $\left(\mathrm{X}_{1}\right)$ terhadap variabel Kenaikan Pendapatan $(\mathrm{Y})$ adalah signifikan. Hal ini berarti $\mathrm{H}_{0}$ ditolak $\mathrm{H}_{\mathrm{a}}$ diterima. Sehingga apabila Pemanfaatan Teknologi Informasi meningkat maka Kenaikan Pendapatan akan mengalami peningkatan. Besar pengaruh variabel Pemanfaatan teknologi informasi $\left(\mathrm{X}_{1}\right)$ terhadap variabel Kenaikan Pendapatan $(\mathrm{Y})=0,069(6,9 \%)$

Hasil uji t variabel Sosialisasi Pajak $\left(\mathrm{X}_{2}\right)$ terhadap variabel Kenaikan pendapatan $(\mathrm{Y})$ menghasilkan nilai signifikansi t sebesar 0,000 . Hasil pengujian tersebut menunjukkan bahwa Sig. $\mathrm{t}<$ alpha $(0,05)$ maka pengaruh variabel Sosialisasi Pajak $\left(\mathrm{X}_{2}\right)$ terhadap variabel Kenaikan pendapatan (Y) adalah signifikan. Besar pengaruh variabel Sosialisasi Pajak $\left(\mathrm{X}_{2}\right)$ terhadap variabel Kenaikan pendapatan $(\mathrm{Y})=0,162(16,2 \%)$. Hal ini berarti $\mathrm{H}_{0}$ ditolak $\mathrm{H}_{\mathrm{a}}$ diterima. Sehingga apabila Sosialisasi Pajak meningkat maka Kenaikan Pendapatan akan mengalami peningkatan.

Hasil uji t variabel Pengetahuan Pajak $\left(\mathrm{X}_{3}\right)$, terhadap variabel Kenaikan pendapatan (Y) menghasilkan nilai signifikansi t sebesar 0,095 . Hasil pengujian tersebut menunjukkan bahwa Sig. $t>$ alpha $(0,05)$ maka pengaruh variabel Pengetahuan Pajak $\left(\mathrm{X}_{3}\right)$ terhadap variabel Kenaikan pendapatan (Y) adalah tidak signifikan. Besar pengaruh variabel Pengetahuan pajak $\left(\mathrm{X}_{3}\right)$ terhadap variabel Kenaikan pendapatan $(\mathrm{Y})=0,084(8,4 \%)$. Hal ini berarti $\mathrm{H}_{0}$ diterima $\mathrm{H}_{\mathrm{a}}$ ditolak. Sehingga apabila Pengetahuan Pajak meningkat maka Kenaikan pendapatan pajak tidak akan mengalami peningkatan.

Hasil uji t variabel Ketepatan Penyampaian SPT $\left(\mathrm{X}_{4}\right)$ terhadap variabel Kenaikan pendapatan (Y) menghasilkan nilai signifikansi t sebesar 0,000. Hasil pengujian tersebut menunjukkan bahwa Sig. $\mathrm{t}>$ alpha $(0,05)$ maka pengaruh variabel Ketepatan Penyampaian SPT $\left(\mathrm{X}_{4}\right)$ terhadap variabel Kenaikan pendapatan (Y)adalah signifikan. Besar pengaruh variabel Ketepatan Penyampaian SPT $\left(\mathrm{X}_{4}\right)$ terhadap variabel kenaikan pendapatan $(\mathrm{Y})=0,723$ $(72,3 \%)$. Hal ini berarti $\mathrm{H}_{0}$ ditolak $\mathrm{H}_{\mathrm{a}}$ diterima. Sehingga apabila Ketepatan Penyampaian SPT meningkat maka Kenaikan pendapatan pajak akan mengalami peningkatan.

\subsection{Uji Simultan (Uji F)}

Tabel 2. Anova

\begin{tabular}{lllllll}
\hline \multirow{2}{*}{ Model } & & Sum & of & & & \\
\hline \multirow{2}{*}{1} & & Squares & Df & Mean Square & F & Sig. \\
\cline { 2 - 7 } & Regression & 615,738 & 4 & 153,934 & 1594,347 &, $000^{\mathrm{b}}$ \\
\cline { 2 - 7 } & Residual & 9,172 & 95 &, 097 & & \\
\cline { 2 - 6 } & Total & 624,910 & 99 & & & \\
\hline
\end{tabular}

Uji simultan (Uji F) dilakukan untuk mengetahui apakah variabel bebas secara simultan (bersama-sama) mempunyai pengaruh terhadap variabel terikat. Cara pengambilan keputusan dengan membandingkan signifikansi $F$ dengan nilai alpha $(\alpha)$ yaitu 0,05 . Apabila signifikansi $\mathrm{F}<0,05$ maka $\mathrm{H}_{0}$ ditolak dan $\mathrm{H}_{\mathrm{a}}$ diterima. Artinya variabel bebas berpengaruh secara simultan terhadap variabel terikat. Sedangkan, Apabila signifikansi $\mathrm{F}>0,05$ maka $\mathrm{H}_{0}$ diterima dan $\mathrm{H}_{\mathrm{a}}$ ditolak. Artinya variabel bebas tidak berpengaruh secara simultan terhadap variabel terikat.

Berdasarkan tabel 3 menunjukkan bahwa koefisien determinasi (R square) sebesar 0,985 . Hal ini menunjukkan bahwa pemanfaatan teknologi informasi $\left(\mathrm{X}_{1}\right)$, sosialisasi pajak $\left(\mathrm{X}_{2}\right)$, pengetahuan pajak $\left(\mathrm{X}_{3}\right)$ dan ketepatan penyampaian SPT $\left(\mathrm{X}_{4}\right)$ berpengaruh sebesar $98,5 \%$ terhadap Kenaikan Pendapatan. Sedangkan sisanya 1,5\% dipengaruhi oleh variabel-variabel lain yang tidak termasuk dalam penelitian ini. 
Tabel 3. Koefesien Determinasi

\begin{tabular}{llllll}
\hline Model & $\mathbf{R}$ & R Square & $\begin{array}{l}\text { Adjusted } \\
\text { Square }\end{array}$ & $\mathbf{R}$ & $\begin{array}{l}\text { Std. Error of the } \\
\text { Estimate }\end{array}$ \\
\hline 1 & $0,993^{\mathrm{a}}$ & 0,985 & 0,985 & 0,311 \\
\hline
\end{tabular}

\section{Kesimpulan}

- Pengaruh variabel Pemanfaatan teknologi informasi $\left(\mathrm{X}_{1}\right)$ terhadap variabel Kenaikan Pendapatan $(\mathrm{Y})=0,069(6,9 \%)$. Hasil uji t variabel Pemanfaatan teknologi informasi $\left(\mathrm{X}_{1}\right)$ terhadap variabel Kenaikan Pendapatan (Y) menghasilkan nilai signifikansi t sebesar 0,009 $<0,05$. Hal ini berarti $\mathrm{H}_{0}$ ditolak $\mathrm{H}_{\mathrm{a}}$ diterima. Sehingga apabila Pemanfaatan Teknologi Informasi meningkat maka Kenaikan Pendapatan pajak juga meningkat.

- Pengaruh variabel Sosialisasi Pajak $\left(\mathrm{X}_{2}\right)$ terhadap variabel Kenaikan pendapatan $(\mathrm{Y})=0,162$ $(16,2 \%)$. Hasil uji t variabel Sosialisasi Pajak $\left(\mathrm{X}_{2}\right)$ terhadap variabel Kenaikan pendapatan (Y) menghasilkan nilai signifikansi t sebesar 0,000. Hal ini berarti $\mathrm{H}_{0}$ ditolak $\mathrm{H}_{\mathrm{a}}$ diterima. Sehingga apabila Sosialisasi Pajak meningkat maka Kenaikan pendapatan pajak juga akan meningkat

- Pengaruh variabel Pengetahuan Pajak $\left(\mathrm{X}_{3}\right)$ terhadap variabel Kenaikan pendapatan $(\mathrm{Y})=$ $0,084(8,4 \%)$. Hasil uji t variabel Pengetahuan Pajak $\left(\mathrm{X}_{3}\right)$, terhadap variabel Kenaikan pendapatan (Y) menghasilkan nilai signifikansi t sebesar 0,095. Hasil pengujian tersebut menunjukkan bahwa Sig. $\mathrm{t}>$ alpha $(0,05)$ maka pengaruh variabel Pengetahuan Pajak $\left(\mathrm{X}_{3}\right)$ terhadap variabel Kenaikan pendapatan (Y) adalah tidak signifikan. Hal ini berarti $\mathrm{H}_{0}$ diterima $\mathrm{H}_{\mathrm{a}}$ ditolak. Sehingga apabila Pengetahuan Pajak meningkat maka Kenaikan pendapatan pajak tidak berpengaruh.

- Besar pengaruh variabel Ketepatan Penyampaian SPT $\left(\mathrm{X}_{4}\right)$ terhadap variabel kenaikan pendapatan $(\mathrm{Y})=0,723(72,3 \%)$. Hasil uji t variabel Ketepatan Penyampaian SPT $\left(\mathrm{X}_{4}\right)$ terhadap variabel Kenaikan pendapatan (Y) menghasilkan nilai signifikansi t sebesar 0,000. Hal ini berarti $\mathrm{H}_{0}$ ditolak $\mathrm{H}_{a}$ diterima. Sehingga apabila Ketepatan Penyampaian SPT meningkat maka Kenaikan Pendapatan Pajak akan mengalami peningkatan.

- Pemanfaatan teknologi informasi $\left(\mathrm{X}_{1}\right)$, sosialisasi pajak $\left(\mathrm{X}_{2}\right)$, pengetahuan pajak $\left(\mathrm{X}_{3}\right)$ dan ketepatan penyampaian SPT $\left(\mathrm{X}_{4}\right)$ secara bersama-sama berpengaruh sebesar $98,5 \%$ terhadap Kenaikan Pendapatan.

\section{Saran}

- Pengetahuan perpajakan mengenai tarif pajak yang berlaku di Indonesia dirasa masih kurang sosialisasi karena sebagian besar masyarakat masih belum paham cara penghitungan tarif pajak tersebut. Oleh karena itu, disarankan kepada pihak Direktorat Jenderal Pajak (DJP) untuk menambah intensitas sosialisasi kepada masyarakat.

- Penyuluhan pajak oleh DJP masih perlu ditingkatkan. Penyuluhan tersebut sebaiknya difokuskan pada pemahaman mengenai hal-hal mendasar seperti hak dan kewajiban wajib pajak.

- Tingkat kesadaran wajib pajak dalam membayar pajak dan melaporkan SPT tergolong masih rendah. Pihak DJP disarankan secara konsisten untuk melakukan upaya-upaya untuk mendekatkan pelayanan perpajakannya, misalnya dengan mobil pajak keliling.

- Tingkat kepatuhan wajib pajak dalam melakukan perhitungan pajak dengan benar juga masih rendah sehingga perlu untuk ditingkatkan lagi. Pihak DJP disarankan untuk lebih 


\section{Lidia Andiani}

meningkatkan sosialisasi mengenai cara perhitungan pajak yang benar sesuai tarif yang berlaku.

- Pendapatan dipengaruhi oleh variabel Pemanfaatan teknologi informasi sosialisasi pajak , pengetahuan pajak dan ketepatan penyampaian SPT sebesar 98,5\% dan 1,5\% sisanya dipengaruhi oleh variabel lain yang tidak dijelaskan dalam penelitian ini. Untuk itu perlu adanya penelitian lebih lanjut mengenai faktor-faktor lain yang mempengaruhi Pendapatan.

Bagi peneliti selanjutnya dapat menggunakan variabel lainnya sehingga untuk selanjutnya dapat ditemukan variabel baru yang akan mempengaruhi tingkat kepatuhan wajib pajak. Selain itu, disarankan untuk melakukan observasi penelitian yang lebih banyak sehingga data yang dihasilkan akan lebih akurat dan memungkinkan untuk dilakukan generalisasi

\section{Daftar Pustaka}

Anggraeni, R, 2007, Faktor-faktor yang Mempengaruhi Wajib Pajak Orang Pribadi di Kawasan Sidoarjo Barat Tidak Mengisi Sendiri SPT Tahunannya. Unpublished undergraduate thesis, Universitas Kristen Petra, Surabaya.

Arikunto, S, 2002, Prosedur Penelitian Suatu Pendekatan Praktek, Rineka Cipta, Jakarta.

Arikunto, S. 2010. Prosedur Penelitian: Suatu Pendekatan Praktik (Edisi Revisi). Cetakan ke14. PT Rineka Cipta : Jakarta.

Aryobimo, Putut Tri. 2012. Pengaruh Persepsi Wajib Pajak tentang Kualitas Pelayanan Fiskus terhadap Kepatuhan Wajib Pajak dengan Kondisi Keuangan Wajib Pajak dan Preferensi Risiko sebagai Variabel Moderating (studi empiris terhadap Wajib Pajak Orang Pribadi di Kota Semarang). Jurnal S1 Jurusan Akuntansi Fakultas Ekonomika dan Bisnis Universitas Diponegoro,Semarang.

Avianto, Gusma. 2016. Analisis Peranan E-Filing Dalam Rangka Meningkatkan Kepatuhan Pelaporan Surat Pemberitahuan Tahunan Wajib Pajak Orang Pribadi . PS Perpajakan, Jurusan Administrasi Bisnis, Fakultas Ilmu Administrasi, Universitas Brawijaya)

Devano, Sony dan Siti Kurnia Rahayu, 2006, Perpajakan : Konsep,Teori dan Isu. Jakarta : Prenada Media Grup.

Direktorat Jenderal Pajak. 2014. Peraturan Direktur Jenderal Pajak Nomor PER-06/PJ./2014 tentang Tata Cara Penyampaian Surat Pemberitahuan Tahunan Bagi Wajib Pajak Orang Pribadi Yang Menggunakan Formulir 1770 S atau 1770 SS Secara E-filing dan Merupakan Pegawai Tetap Pada Pemberi Kerja Tertentu.

Djudi, Muhammad. 2014. Pengaruh Pengetahuan Perpajakan Dan Kualitas Pelayanan Terhadap Kesadaran Wajib Pajak Dalam Menyampaikan Surat Pemberitahuan (Spt) Tahunan). Program Studi Perpajakan, Jurusan Administrasi Bisnis, Fakultas Ilmu Administrasi Universitas Brawijaya

Faisal, S. 2008. Format-format Penelitian Sosial. Edisi 1. Jakarta: Rajawali Pers.

Ghozali, Imam, 2009, Aplikasi Analisis Multivariate Dengan Program SPSS, Edisi.Keempat, Penerbit Universitas Diponegoro Semarang

Hasan, M. I. (2002). Pokok-pokok materi metodologi penelitian dan aplikasinya.

Nurmantu, Safri. 2003. Pengantar Perpajakan. Granit: Jakarta

Nurmantu. 2005. Pengantar Perpajakan, Edisi 2. Jakarta: Yayasan Obor Indonesia

Resmi, S. 2009.Perpajakan Teori dan Kasus, Jakarta:Penerbit Salemba Empat

Resmi. 2012. Perpajakan Teori dan Kasus. Jakarta: Salemba Empat

Richardson, G. (2006). Determinants of tax evasion: A cross-country investigation. Journal of international Accounting, Auditing and taxation, 15(2), 150-169.

Seksi Pengolahan Data dan Informasi Kantor Pelayanan Pajak Pratama Blitar

Sudrajad, Ajat. 2015. Pemanfaatan teknologi Informasi, Sosialisasi Pajak, Pengetahuan

Perpajakan, dan Kepatuhan Pajak, Universitas pancasila, Jakarta

Sugiyono, 2007, Metode Penelitian Bisnis. Penerbit CV. Alfabeta, Bandung

Sugiyono, 2009, Statistika Untuk Penelitian, CV. Alfabeta, Bandung. 


\section{Lidia Andiani}

Sugiyono, 2011, Metode Penelitian Kuantitatif Kualitatif dan R\&D, Penerbit Alfabeta, Bandung

Sugiyono, 2012, Metode Penelitian Kuantitatif Kualitatif dan $R \& D$, Penerbit Alfabeta, Bandung.

Sugiyono, 2013, Metode Penelitian Pendidikan Pendekatan Kuantitatif, Kualitatif, dan $R$ \& D, Penerbit Alfabeta, Bandung.

Suryadi, Imam. 2016. Pengaruh Sosialisasi Perpajakan, Sanksi Administrasi Dan Tingkat Pemahaman Wajib Pajak Terhadap Tingkat Kepatuhan Wajib Pajak Orang Pribadi Dalam Memenuhi Kewajibannya.Program Studi Perpajakan, Jurusan Administrasi Bisnis, Fakultas Ilmu Administrasi Universitas Brawijaya,

Susanto, Joko. 2011. Mencermati Kepatuhan Pajak. http://www.suarakaryaonline.com/news.html?id=275176 (9 November 2015)

Wulansari, Arinta. 2015. Pengaruh Penerapan Sanksi Perpajakan, Kesadaran Dan Kepatuhan Wajib Pajak Terhadap Ketepatan Pelaporan Spt Wajib Pajak Orang Pribadi Di Kpp Pratama Kepanjen Jurnal S1 Jurusan Akuntansi Fakultas Ekonomi Universitas Kanjuruhan Malang.

Yadnyana, I Ketut, 2009, Pengaruh Moral dan Sikap Wajib Pajak pada Kepatuhan Wajib Pajak Koperasi di Kota Denpasar. Denpasar: Fakultas Ekonomi Universitas Udayana. 